\title{
Erratum to: Avian abundance thresholds, human-altered landscapes, and the challenge of assemblage-level conservation
}

\author{
Kevin J. Gutzwiller • Curtis H. Flather
}

Published online: 26 March 2016

(C) Springer Science+Business Media Dordrecht 2016

\section{Erratum to: Landscape Ecol DOI 10.1007/s10980-015-0233-1}

The original publication of the article includes incorrect common and scientific names for a bird species listed in Tables S4 and S10 in the online Supplementary Material.

Instead of Bell's Sparrow (Artemisiaspiza belli), the correct names for the species we studied are Sagebrush Sparrow (Artemisiospiza nevadensis).

The online version of the original article can be found under doi:10.1007/s10980-015-0233-1.

\section{K. J. Gutzwiller $(\bowtie)$}

Department of Biology, Baylor University, Waco,

TX 76798, USA

e-mail: kevin_gutzwiller@baylor.edu

C. H. Flather

Rocky Mountain Research Station, USDA Forest Service,

Fort Collins, CO 80526, USA 